\title{
Ethanol Production from Paddy Straw using Partially Purified Fungal Cellulase
}

\author{
Monika Agarwal ${ }^{1}$, Annu Goel ${ }^{2 *}$ and Leela Wati ${ }^{3}$ \\ ${ }^{3}$ Principal Scientist, ${ }^{1}$ Department of Microbiology, CCS Haryana Agricultural University, \\ Hisar-125 004, India \\ ${ }^{2}$ Research Associate, Central Pollution Control Board, Delhi 110032, India \\ *Corresponding author
}

\section{Keywords}

Agricultural wastes,

Bio-ethanol,

Cellulase,

Lignocellulosic,

Paddy straw.

Article Info

Accepted:

20 July 2018

Available Online:

10 August 2018

\section{A B S T R A C T}

In an endeavour of exploring alternative energy sources to petroleum based fuels, bioethanol (ethanol derived from biomass) is considered as the most promising renewable fuel because of its potential to cut greenhouse gas emissions by $86 \%$ and higher octane (ability to resist compression) rating than gasoline. Present investigation was aimed at bioconversion of paddy straw to ethanol using partially purified fungal cellulases. A variety of soil samples were tested for the presence of cellulolytic fungal strains using enrichment culture technique. Fungal strains were selected based on the diameter of clearance zone on carboxymethylcellulose (CMC) agar plates. Selected strains were tested for the cellulase $v i z$., exoglucanase and endoglucanase activities before and after partial purification. Out of the 10 selected cellulolytic fungal isolates, F-1 isolate has the highest $0.42 \mathrm{IU} / \mathrm{ml}$ exoglucanase and $1.66 \mathrm{IU} / \mathrm{ml}$ endoglucanase activities. Enzyme production was maximum in Mandels and Sternberg medium containing delignified paddy straw as carbon source at $30^{\circ} \mathrm{C}$ after 7 days' incubation with 0.66 and $2.52 \mathrm{IU} / \mathrm{ml}$ exoglucanase and endogluanase activities, respectively. Ammonium sulfate saturation at $50-55 \%$ followed by dialysis resulted in the partial purification of crude cellulase enzyme with2.8 and 2.1 folds' increase in exoglucanase and endogluanase activities, respectively. Hydrolysis of delignified paddy straw using partially purified enzyme obtained from $\mathrm{F}-1$ isolate resulted in $63.7 \%$ solubilization of polysaccharide fraction at $50^{\circ} \mathrm{C}$ after $4 \mathrm{~h}$ reaction time.

\section{Introduction}

Rapidly depleting fossil fuels and environmental pollution have led to a worldwide search for alternative fuels. Ethanol can be used as fuel as gasohol in addition to other applications in industries which need production of alcohol on large scale. Many efforts have been made in recent years to enhance ethanol production from different sources (Galbe and Zacchi, 2002). Molasses based ethanol production is limited by the production of sugarcane in the country. Bioethanol can be produced from other sugar (from sugarcane) or starch (from maize, cassava etc.) based feedstock but the choice of 
biological feedstock, environmental variables and the organism determines the efficiency of ethanol production process. Sugar and starch rich food crops are an integral part of animal and human food chain and as the global population has increased their use in producing bio-ethanol has been criticized for diverting food away from the human and animal food chain, leading to food shortage and price rise (Goel and Wati, 2013).

The cheap and abundant sugar polymer, found as agricultural wastes (wheat straw, corn stalks, soybean residues, sugar cane bagasse etc.) and industrial wastes (pulp and paper industry) accounts for about $50 \%$ of the biomass in the world (Classen et al., 1999).Effective utilization of cellulosic materials through bioprocesses will be an important key to overcome the shortage of fuels (Ohmiya et al., 1997). Paddy straw is one of the most abundant lignocellulosic waste materials in the world. In terms of total production, rice is the third most important grain crop in the world after wheat and corn.High silica content of paddy straw makes it unfit for animal feed and its disposal by burning is banned due to air pollution causing pulmonary morbidity and mortality (Binod et al., 2010). The best alternative for handling such a huge quantum of biomass is the production of commercially important valueadded products like ethanol (Oberoi et al., 2010).

The bioconversion of paddy straw to ethanol is a multi-step process consisting of pretreatment, hydrolysis and fermentation. Without any pretreatment, the conversion of native cellulose to sugar is extremely slow, as cellulose is well protected by the matrix of lignin and hemicellulose in macrofibrils. Therefore, pretreatment of paddy straw is necessary to increase the rate of hydrolysis of cellulose to fermentable sugars (Galbe and Zacchi, 2002). The cellulose and hemicellulose can be hydrolyzed to fermentable sugars either by chemical or biological means, the later employing enzymes i.e. cellulases and hemicellulases (Goel and Wati, 2013).The enzymatic hydrolysis is preferred because of high specificity, lower cost and purity of the end products. Cellulases are usually a mixture of several enzymes. Three major groups of cellulases involved in the hydrolysis processare: 1. endoglucanase, which attacks regions of low crystallinity in the cellulose fiber, creating free chain-ends 2. exoglucanase or cellobiohydrolase, which degrades the molecule further by removing cellobiose units from the free chain-ends and 3. glucosidase, which hydrolyzes cellobiose to produce glucose glucose (Coughlan and Ljungdahl, 1988). Conversion of lignocellulosic biomass to fermentable sugars mainly depends on the degradation capacity of a range of biomassdegrading enzymes produced by many cellulolytic microorganisms (Kovacs et al., 2009). The lack of a microorganism able to produce cellulase enzyme efficiently is one of the limiting factors for utilization of lignocellulosic wastes like paddy straw to ethanol. The present investigation was, therefore, carried out to isolate an efficient cellulase producer fungal strain and standardization of environmental variables for maximum enzyme production followed by partial purification of enzyme for efficient polysaccharide hydrolysis of paddy straw for ethanol production.

\section{Materials and Methods}

Soil samples for cellulolytic fungal isolates were collected from various locations of University farm of CCS HAU, Hisar and nearby areas. Paddy straw of Pusa-1 variety was procured from farmers' fields and dried at $50^{\circ} \mathrm{C}$. The standard culture of Trichoderma reesei MTCC 3194 was obtained from Institute of Microbial Technology (IMTECH), 
Chandigarh and maintained on Potato Dextrose Agar slants containing potatoes 250.0; dextrose 20.0 and agar-agar 20.0 (g/L) at $4 \pm 1{ }^{\circ} \mathrm{C}$. A fast fermenting yeast strain of Saccharomyces cerevisiae HAU-1 was procured from culture collection, Department of Microbiology, CCS HAU, Hisar and maintained on yeast extract peptone dextrose agar slants containing dextrose 20.0; Yeast extract 10.0; peptone 20.0 and agar-agar 20.0 $(\mathrm{g} / \mathrm{L})$ at $4 \pm 1^{\circ} \mathrm{C}$.Commercial liquid cellulase (Palkosoft super 720) was obtained from MAPS India Limited, Ahmedabad, Gujarat.

\section{Isolation and screening of cellulolytic fungal strains}

Fungal strains for cellulase production potential were isolated from soil using enrichment culture technique in Mineral salt medium (Mandels and Sternberg, 1976) containing: Cellulose 10.0; Potassium hydrogen phosphate 2.0; Ammonium sulfate 1.4; Urea 0.3; Magnesium sulphate 0.3, Calcium chloride 0.3, Trace element solution $1.0 \mathrm{ml}$ (Manganese sulphate 1.56, Ferrous sulphate 5.00, Zinc chloride 1.67 and Cobalt chloride 2.00) and Tween $800.5(\mathrm{~g} / \mathrm{L})$.Ten gram of soil sample was inoculated in $100 \mathrm{ml}$ of Mineral salt medium followed by incubation at $28 \pm 2^{0} \mathrm{C}$ on rotary shaker (140 rpm).Samples $(0.1 \mathrm{ml})$ were withdrawn at intervals of 7, 14, 21 and 30 days and spread on cellulose agar plates(Cellulose: 20.0; DiPotassium hydrogen phosphate: 0.8; Potassium di-hydrogen phosphate: 0.2; Magnesium sulphate: 0.2; Sodium chloride: 0.2; Sodium nitrite: 0.1; Yeast extract: 20.0; pH: 7.0; Agar-Agar: 20.0)and incubated at $28+2^{\circ} \mathrm{C}$ for 7 days. Fungal isolates thus obtained were purified by re-transferring them on fresh cellulose agar plates and screened for cellulase activity by spot plating on culture plates containing carboxymethyl cellulose agar (carboxymethyl cellulose 5.0; Glucose 20.0; Yeast extract 5.0 and agar-agar 15.0 $\mathrm{g} / \mathrm{L})$. Inoculated plates were incubated at $28^{\circ} \mathrm{C}$ for 48 hours and observed for clearance zone by flooding the plates with $0.1 \%$ aqueous solution of congo red for 15-20 minutes followed by destaining with $1 \mathrm{M} \mathrm{NaCl}$ for 1520 minutes. Clear zone diameter was calculated by taking the ratio of clear zone diameter to colony diameter.

\section{Standardization of conditions for optimum cellulase production}

Culture conditions for the selected fungal isolate were standardized with respect to incubation temperature $\left(30-35^{\circ} \mathrm{C}\right)$, time $(5-10$ days) and carbon source (Cellulose and paddy straw) for maximum cellulase production.

\section{Ethanol production from paddy straw}

Particlesize of dried paddy straw was reduced using Wiley grinder fitted with sieve of mesh size $0.5 \mathrm{~mm}$ for efficient delignification. Delignification of paddy straw $(0.5 \mathrm{~mm})$ was carried out using alkali treatment ( $2 \%$ sodium hydroxide) at 1:10 (solid: liquid)at high temperature $\left(121^{\circ} \mathrm{C}\right)$ in an autoclave at $15 \mathrm{psi}$ for 1 hour (Wati et al., 2007). Delignified paddy straw was filtered, washed to neutral under tap water and dried to moisture free in hot air oven at $50^{\circ} \mathrm{C}$. Dried delignified paddy straw was hydrolyzed using partially purified cellulase of selected fungal isolate. Hydrolysis conditions were standardized with respect to temperature $\left(50,55\right.$ and $\left.60^{\circ} \mathrm{C}\right)$, incubation time (1, 2, 3 and $4 \mathrm{~h})$ and substrate enzyme ratio $(1: 1, \quad 1: 2$ and $1: 3)$ for maximum solubilisation of cellulose. The saccharification (\%) by selected fungal isolate was compared with the standard culture of $T$. reseei MTCC 3194.

The hydrolysate obtained under optimal conditions was cooled down to $35^{\circ} \mathrm{C}$ and fermented with yeast biomass inoculated at $0.5 \%(\mathrm{w} / \mathrm{v})$ supplemented with yeast nutrients 
(Yeast extract 0.5; Urea0.3; Disodium hydrogen phosphate $0.15 \%$ ) at $30^{\circ}$ Cand ethanol production was compared with commercial cellulase enzyme (Palkosoft super 720).

\section{Analytical Methods}

Exoglucanase activity of cellulase enzyme was estimated according to the method recommended by IUPAC using Whatmann filter paper no. 1 as substrate (Ghosh, 1987). The endoglucanase activity was measured as the rate of reducing sugars formed during hydrolysis of $1 \%$ carboxymethylcellulose at $\mathrm{pH}-4.8$ at $50^{\circ} \mathrm{C}$. The total reducing sugars were estimated using the 3, 5-dinitrosalicylic acid (DNS) method (Miller, 1959).Ethanol content was estimated by the method described by Caputi et al., (1968). Partial purification of crude cellulase was carried out by ammonium sulfate fractionation (Green and Hughes, 1955) followed by dialysis in citrate buffer (0.1 M; pH-6.0) for 24 hours. The cellulose, hemicellulose and lignin content of paddy straw were estimated by determining acid detergent fibre (ADF) and neutral detergent fibre (NDF) in the samples (AOAC, 2000).Total soluble proteins were estimated by the method of Lowry et al., 1951.

\section{Results and Discussion}

Isolation and screening of cellulolytic fungal strains

The inoculation of different soil samples on enrichment culture media led to the isolation of 10 fungal strains which were cellulolytic in nature. Out of 10 isolated cultures, 4 were mycelial and 6 were spore forming. The colony morphology varied form circular to irregular, size small to large and margin lobate to undulate with varying spore color (Table 1). The clearance zone diameter of isolated fungal strains on carboxymethyl cellulose agar plates ranged from 1.6 to $7.0 \mathrm{~mm}$ with $\mathrm{F}-1$ strain showed the largest clearance zone $(7.0 \mathrm{~mm}$ diameter). This was found to be comparable yet less than the standard culture of Trichoderma reesei MTCC 3194 with $8.0 \mathrm{~mm}$ clearance zone diameter (Table 1).

In liquid Mandels and Sternberg medium, exoglucanase activity of the fungal isolates ranged between 0.06 to $0.42 \mathrm{IU} / \mathrm{ml}$ while endoglucanase ranged between 0.27 to 1.66 $\mathrm{IU} / \mathrm{ml}$. The isolate F-1 had highest exoglucanase (0.42) and endoglucanase (1.66) while standard culture MTCC 3194 had 0.48 $\mathrm{IU} / \mathrm{ml}$ exoglucanase and $1.71 \mathrm{IU} / \mathrm{ml}$ endoglucanase (Fig. 1).

Based on the clearance zone diameter and cellulase (exoglucanase and endoglucanase) activities, fungal strain F-1 was selected for further study and findings were compared with the standard culture of Trichoderma reesei MTCC 3194.

\section{Standardization of conditions for optimum cellulase production}

Cellulase production potential of the fungal strain can be changed by altering the cultural conditions. To study the effect of carbon source, delignified paddy straw (mesh size 0.5 $\mathrm{mm}$; cellulose 62\%; hemicellulose $13 \%$ and lignin 2\%) was used in Mandels and Sternberg medium in place of cellulose. Both the exoglucanase and endoglucanase activities of F-1 isolate increased from 0.42 to $0.66 \mathrm{IU} / \mathrm{ml}$ and 1.66 to $2.52 \mathrm{IU} / \mathrm{ml}$, respectively on replacing delignified paddy straw with cellulose. To optimize incubation temperature for cellulase production the selected cultures were grown at varied temperature $\left(30^{\circ} \mathrm{C}\right.$ and $35^{\circ} \mathrm{C}$ ) and enzyme activity was measured after 7 days. It was observed that both the cultures F-1 and MTCC 3194 showed maximum cellulase activity of 0.66 and $0.77 \mathrm{IU} / \mathrm{ml}$ exoglucanase and 2.52 and $2.76 \mathrm{IU} / \mathrm{ml}$ 
endoglucanase, respectively at temperature $30^{\circ} \mathrm{C}$ (Table 2). With further increase in temperature enzyme activity decreased. Cellulase activity increased with incubation time up to 7 days reaching maximum value of $0.66 \mathrm{IU} / \mathrm{ml}$ exoglucanase and $2.52 \mathrm{IU} / \mathrm{ml}$ endoglucanase for the F-1 and became almost constant afterwards (Fig. 2).

Based on these findings, the selected fungal isolate was grown in Mandels and Sternberg medium having delignified paddy straw as carbon source at $30^{\circ} \mathrm{C}$ for 7 days for maximum cellulase production.

\section{Partial purification of cellulase}

Cellulase is an extracellular enzyme and needs to be studied in purified form for its commercial application. Therefore, for characterization it must be purified from culture filtrate. The partial purification of F-1 isolate and 3194 was carried out using ammonium sulfate saturation by observing the precipitates and precipitates were observed maximally at 50-55\% saturation. Cellulase activity in partially purified enzyme of F-1 isolate increased from 0.66 to $1.875 \mathrm{IU} / \mathrm{ml}$ exoglucanase and 2.52 to $5.22 \mathrm{IU} / \mathrm{ml}$ endoglucanase with 2.1 and 2.8-fold increase, respectively while for MTCC 3194 there was 2.60-fold increase in exoglucanase and 2.06fold increase in endoglucanase activity (Table 3). Protein analysis of crude and partially purified enzyme indicated 3.45-fold increase in specific activity of partially purified cellulase of F-1 and 3.5 folds' increase in specific activity of partially purified cellulase of MTCC 3194 (Table 4).

\section{Ethanol production from paddy straw}

The delignified paddy straw was hydrolyzed using partially purified cellulase enzyme of F1 isolate and compared with the amount of reducing sugars released using partially purified enzyme of MTCC 3194 and commercial cellulase. It was found that $65 \%$ reducing sugars were release dusing commercial enzyme loaded at $5 \mathrm{FPU} / \mathrm{g}$ delignified paddy straw at $50^{\circ} \mathrm{C}$ after 4 hours' incubation while in case partially purified cellulase of F-1 and MTCC 3194 (loaded at 5 FPU/g) reducing sugars released was 50.5 and $55.5 \%$, respectively under similar conditions. Paddy straw hydrolysate obtained after treatment with partially purified cellulase of F1 isolate and MTCC 3194 on fermentation with $S$. cerevisiae resulted in production of $2.8 \%$ and $3.0 \%$ ethanol (v/v), respectively while hydrolysate obtained after commercial enzyme treatment generated $3.5 \%$ ethanol (v/v) (Table 5).

Currently, ethanol is widely considered to be one of the most important alternatives to petroleum. Lignocellulosic feedstock, due to their abundance and low cost, has become attractive raw materials for ethanol production compared to starch and sucrose-based materials. Fuels derived from lignocellulosic biomass also hold the potential for clean and renewable transportation energy. The current work shows the possibility of successful production of ethanol from paddy straw, by enzymatic hydrolysis followed by fermentation using Saccharomyces cerevisiae.

On analysis it was observed that paddy straw has $36.3 \%$ cellulose, $21 \%$ hemicellulose and $6 \%$ lignin. The composition of paddy straw after alkali treatment was found to be $62 \%$ cellulose, $13 \%$ hemicellulose and 2\%lignin. A similar apparent increase in cellulose from $35.03 \%$ to $73.43 \%$ and decrease in hemicellulose from 24.85 to $16.16 \%$ content after alkali treatment was reported by Goel and Wati (2016). This may be attributed to the fact of lignin and hemicellulose removal. Hemicellulose content decreased due to the low degree of polymerization, amorphous nature and its high solubility in alkali. 
The nature is a great reservoir and has a wide array of microbial diversity. In our study, a total of 10 fungal strains were isolated from different soil samples by enrichment culture method in Mandels and Sternberg medium (Table 1). Cellulolytic microbial strains have been isolated by other researchers using enrichment culture method but from different sources. Shanmugapriya et al., (2012) isolated 5 cellulase producing bacteria from cow dung. Gupta et al., (2012) isolated 08 cellulose degrading bacteria from 04 different invertebrates (termite, snail, caterpillar, and bookworm) by enriching the basal culture medium with filter paper as substrate. Patagundi et al., (2015) isolated 57 cellulase producing bacteria from the soil sample collected from Botanical garden, Karnatak University Campus, Karnataka using 04 different substrates like Acacia arabica pod, Bauhinia forficata pod, Cassia surattensis pod and Peltophorumpterocarpum pods (as cellulose substrate) in the submerged production medium, out of which, 03 cellulolytic bacterial strainsviz., Bacillus cereus $(0.440 \quad \mathrm{IU} / \mathrm{ml} / \mathrm{min}$ and 0.410 $\mathrm{IU} / \mathrm{ml} / \mathrm{min})$, Bacillus $\quad$ subtilis $\quad(0.357$ $\mathrm{IU} / \mathrm{ml} / \mathrm{min}$ ) and Bacillus thuringiensis (0.334 $\mathrm{IU} / \mathrm{ml} / \mathrm{min}$ ) showed maximum enzyme activity to the Acacia arabica pod.

Media optimization is one of the most important aspect of fermentation technology.Both the exoglucanase and endoglucanase activities of F-1 isolate increased from 0.42 to $0.66 \mathrm{IU} / \mathrm{ml}$ and 1.66 to $2.52 \mathrm{IU} / \mathrm{ml}$, respectively on replacing delignified paddy straw with cellulose. Experiments by other researchers also reported that the application of the enzyme that was produced on the same substrate as was used for hydrolysis can be advantageous in the case of some substrates. Juhasz et al., (2005) demonstrated that pretreated corn stover is a good substrate both for enzyme production and hydrolysis, since high cellulolytic activities of fungal isolate $T$. reesei RUT C30 could be reached using it as carbon source whereas Shanmugapriya et al., (2012) reported Carboxy Methyl Cellulose as the best substrate for cellulase production by Bacillus species compared to coir waste and saw dust as substrates. Gaur and Tiwari (2015) reported maximum cellulase production from Bacillus vallismortis RG-07 strain using sugarcane bagasse as carbon source. This difference in observations may be due to the difference in nature of carbon source. Effect of incubation time and temperature on cellulase production was studied and a continuous increase in exoglucanase activity from 0.008 $\mathrm{IU} / \mathrm{ml}$ after 3 days to $0.416 \mathrm{IU} / \mathrm{ml}$ after 6 days was observed in F-1 isolate. Similar trend was observed in endoglucanase activity. Enzyme activity increased up to 7 days with maximum cellulase production of $0.42,0.48 \mathrm{IU} / \mathrm{ml}$ exoglucanase and 1.66, $1.71 \mathrm{IU} / \mathrm{ml}$ endoglucanase for F-1 isolate and MTCC 3194 , respectively suggesting that up to 7 th day, enzyme synthesized all its necessary components. Similar trend was observed for fungal culture MTCC 3194 with maximum exoglucanase activity of 0.765 and endoglucanase activity of $2.76 \mathrm{IU} / \mathrm{ml}$ after 7 days (Table 2 and Fig. 2). Ali and Saad ElDein (2008) studied cellulase production by two local fungal isolates: Aspergillus niger and $A$. nidulans and reported maximum activity for $A$. niger at $35^{\circ} \mathrm{C}, \mathrm{pH} 7.0$, sodium nitrate as nitrogen source and 7 days under static condition whereas for A. nidulans at $30^{\circ} \mathrm{C}$, under similar conditions.

Partial purification of the crude filtrate was done by ammonium sulfate fractionation for improving enzyme activity. Precipitates in crude filtrate of both F-1 and MTCC 3194 culture were obtained at $50-55 \%$ saturation of ammonium sulfate. 
Table.1 Morphological characters of the fungal colonies

\begin{tabular}{|l|l|l|l|l|c|}
\hline $\begin{array}{l}\text { Fungal } \\
\text { Isolate }\end{array}$ & Colony form & Colony size & Margin & Colour & $\begin{array}{c}\text { Clearance zone } \\
\text { diameter }(\mathrm{mm})\end{array}$ \\
\hline F-1 & Circular & Moderate & Entire & Creamy mycelium & 7.0 \\
\hline F-2 & Circular & Small & Undulate & Black spores & 2.8 \\
\hline F-3 & Filamentous & Large & Entire & White filamentous & 2.5 \\
\hline F-4 & Irregular & Small & Undulate & Green spores & 2.2 \\
\hline F-5 & Circular & Moderate & Filliform & Greenish yellow spores & 1.6 \\
\hline F-6 & Circular & Large & Entire & Creamy white mycelium & 1.6 \\
\hline F-7 & Irregular & Large & Lobate & Dark green spores & 3.2 \\
\hline F-8 & Circular & Moderate & Curled & Greenish brown spores & 3.5 \\
\hline F-9 & Irregular & Moderate & Undulate & Greenish pink spores & 1.8 \\
\hline F-10 & Filamentous & Moderate & Entire & White mycelium & 2.5 \\
\hline MTCC & Circular & Large & Entire & Dark green spores & 8.5 \\
\hline 3194 & & & & & \\
\hline
\end{tabular}

Table.2 Effect of incubation temperature on exoglucanase and endoglucanase activity of F-1 isolate and MTCC 3194

\begin{tabular}{|c|c|c|c|c|}
\hline \multirow{2}{*}{ Incubation temperature } & \multicolumn{4}{|c|}{ Enzyme activity (IU/ml) } \\
\cline { 2 - 5 } & \multicolumn{2}{|c|}{ Exoglucanase activity } & \multicolumn{2}{c|}{ Endoglucanase activity } \\
\cline { 2 - 5 } & $\mathbf{F - 1}$ & $\mathbf{3 1 9 4}$ & $\mathbf{F - 1}$ & $\mathbf{3 1 9 4}$ \\
\hline $30^{\circ} \mathrm{C}$ & 0.66 & 0.77 & 2.52 & 2.76 \\
\hline $35^{\circ} \mathrm{C}$ & 0.50 & 0.61 & 2.02 & 2.24 \\
\hline
\end{tabular}

Table.3 Exoglucanase and Endoglucanase activity of crude and partially purified enzyme of F-1 isolate and MTCC 3194

\begin{tabular}{|l|l|l|l|l|}
\hline \multirow{2}{*}{ Enzyme } & \multicolumn{2}{|l|}{ Enzyme activity $(\mathrm{IU} / \mathrm{ml})$} \\
\cline { 2 - 5 } & \multicolumn{2}{l|}{ Exoglucanase activity } & \multicolumn{2}{l|}{ Endoglucanase activity } \\
\cline { 2 - 5 } & F-1 & MTCC 3194 & F-1 & MTCC 3194 \\
\hline Crude & 0.660 & 0.765 & 2.52 & 2.76 \\
\hline Partially Purified & 1.875 & 2.025 & 5.22 & 5.70 \\
\hline
\end{tabular}

Table.4 Specific activity of crude and partially purified enzyme of F-1 isolate and MTCC 3194

\begin{tabular}{|c|c|c|c|c|}
\hline \multirow{2}{*}{ Purification step } & \multicolumn{2}{|c|}{ Crude } & \multicolumn{2}{c|}{ Partially purified } \\
\cline { 2 - 5 } & \multicolumn{2}{|c|}{ F-1 } & $\mathbf{3 1 9 4}$ & \multicolumn{2}{|c|}{ F-1 } & $\mathbf{3 1 9 4}$ \\
\hline Activity (IU/ml) & 2.52 & 2.76 & 5.22 & 5.70 \\
\hline Volume (ml) & 1000 & 1000 & 10 & 10 \\
\hline Total protein $(\mathrm{mg})$ & 1.49 & 1.59 & 0.90 & 0.94 \\
\hline $\begin{array}{c}\text { Specific activity } \\
\text { (IU/mg) }\end{array}$ & 1.69 & 1.74 & 5.80 & 6.07 \\
\hline
\end{tabular}


Fig.1 Cellulase (exoglucanase and endoglucanase) activities of fungal isolates in Mandels and Sternberg Medium

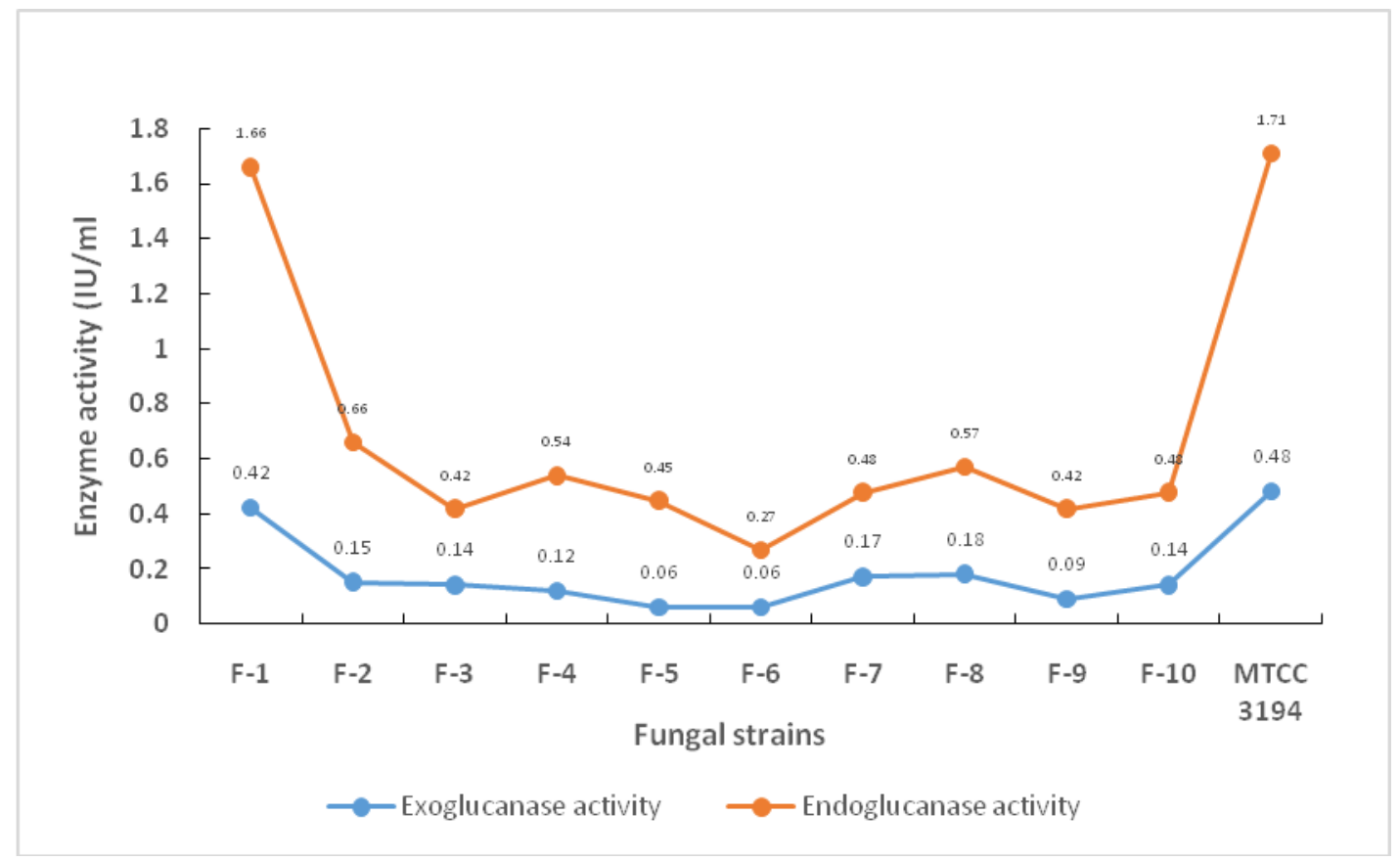

Fig.2 Effect of incubation time on exoglucanase and endoglucanase activities of selected fungal isolate (F-1) and standard fungal strain (MTCC 3194) in Mandels and Sternberg medium

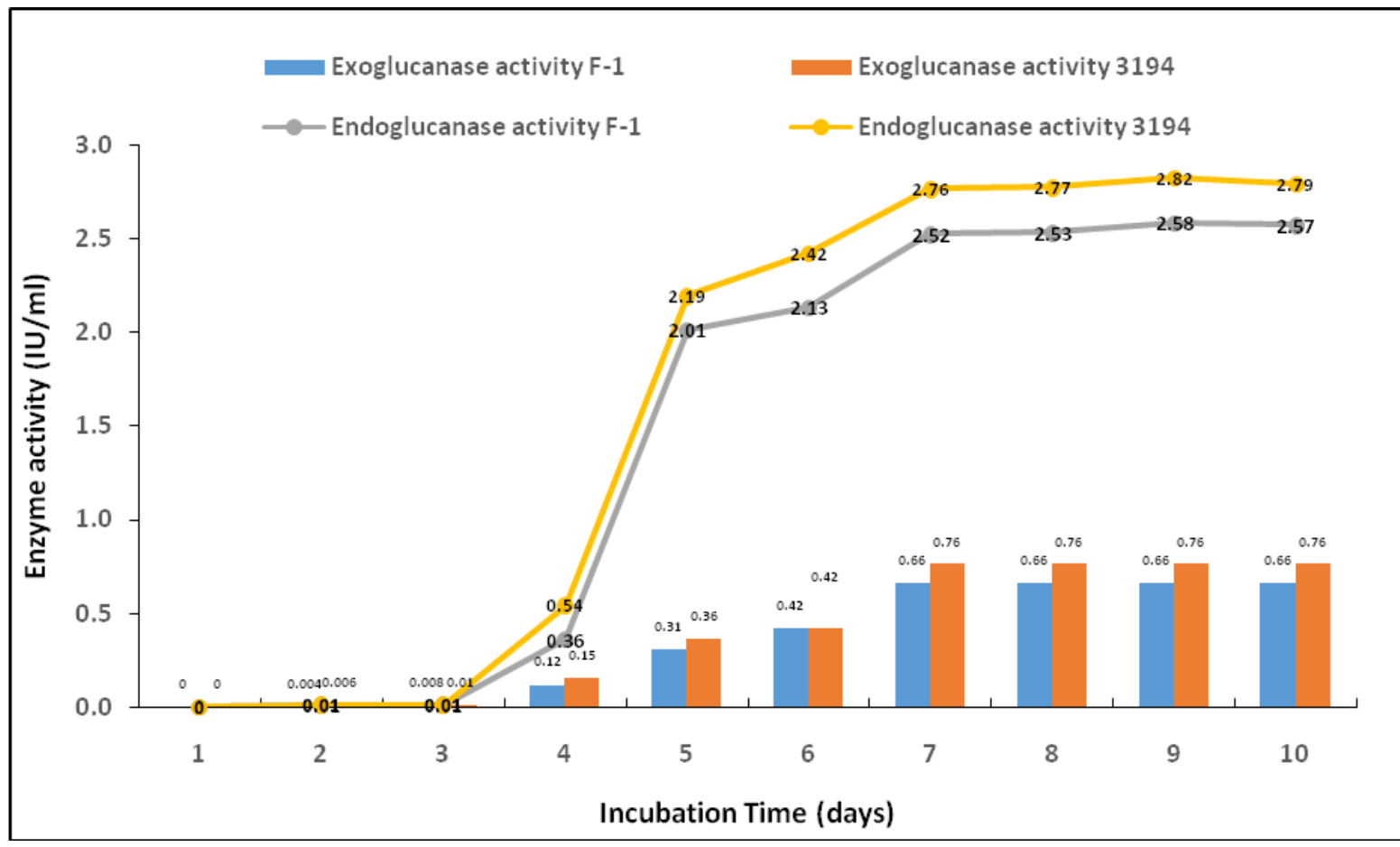


Table.5 Ethanol production from hydrolyzed paddy straw by S. cerevisiae HAU-1 at 30oC

\begin{tabular}{|l|l|l|l|l|}
\hline \multirow{2}{*}{ Treatment } & \multicolumn{2}{l}{ Ethanol (\% v/v) } & $\mathbf{4 8 ~ h}$ & $\mathbf{7 2 ~ h}$ \\
\cline { 2 - 5 } & $\mathbf{2 4} \mathbf{~ h}$ & $\mathbf{3 6 ~ h}$ & 2.7 & 2.8 \\
\hline Partially purified cellulase (F-1) & 1.8 & 2.5 & 2.9 & 3.0 \\
\hline $\begin{array}{l}\text { Partially purified cellulase (MTCC } \\
\text { 3194) }\end{array}$ & 2.0 & 2.7 & 3.3 & 3.5 \\
\hline Commercial enzyme & 2.5 & 3.0 & & \\
\hline
\end{tabular}

Ali and Saad El-Dein, (2008) reported precipitation of the enzyme of Aspergillus niger and A. nidulans at $70 \%$ ammonium sulfate saturation. In our research, cellulase activity in partially purified enzyme of F-1 isolate increased from 0.66 to $1.875 \mathrm{IU} / \mathrm{ml}$ exoglucanaseand 2.52 to $5.22 \mathrm{IU} / \mathrm{ml}$ endoglucanase with 2.1 and 2.8 -fold increase, respectively while for MTCC 3194 there was 2.60-fold increase in exoglucanaseand 2.06fold increase in endoglucanase activity (Table 3 and 4).While Ali and Saad El-Dein, (2008) reported 18.48 folds' increase in CMCase activity for Aspergillus nigerand 17.78 folds' increase in CMCase for Aspergillus nidulans. Ahmed et al.(2009), partially purified three cellulases, exoglucanase (EXG), endoglucanase (EG) and $\beta$-glucosidase (BGL) from $T$. harzianum and found that after final purification step specific activities (IU/mg) of the enzymes were; EXG: 49.22, EG: 0.63 and BGL: 0.35 with $21.87,7.15$ and 1.74 folds' purification, respectively.

Hydrolysis of delignified paddy straw using partially purified enzyme was done by standardizing the conditions. Reducing sugars released after saccharification decreased from 38.2 to $35.6 \%$ on increasing reaction temperature from $50^{\circ} \mathrm{C}$ to $60^{\circ} \mathrm{C}$ when the paddy straw was treated with partially purified enzyme of F-1 isolate. Ethanol production from paddy straw hydrolysed with partially purified F-1 enzyme by $S$. cerevisiae at $30^{\circ} \mathrm{C}$ for $72 \mathrm{~h}$ was $2.8 \%$ (Table 5). Goel and Wati (2013) reported 75\% saccharification of paddy straw biomass at $50^{\circ} \mathrm{C} ; 2 \mathrm{~h}$ incubation time with enzyme loaded at 7.5 FPU/g substrate. Grover et al., (2015) reported $67.64 \%$ total reducing sugars release from alkali treated spent mushroom substrate after $2 \mathrm{~h}$ incubation at $50^{\circ} \mathrm{C}$ with enzyme loaded at $5 \mathrm{FPU} / \mathrm{g}$ substrate. Paddy straw hydrolysate obtained after treatment with partially purified cellulase of F-1 isolate and MTCC 3194 on fermentation with $S$. cerevisiae resulted in production of $2.8 \%$ and $3.0 \%$ ethanol $(\mathrm{v} / \mathrm{v})$, respectively while hydrolysate obtained after commercial enzyme treatment generated $3.5 \%$ ethanol (v/v) (Table 4). Nakamura et al., (2001) studied alcohol fermentation of an enzymatic hydrolysate of steam exploded rice straw and reported an ethanol yield of $8.6 \%(\mathrm{w} / \mathrm{w})$. Gurav and Geeta (2007) also reported the maximum ethanol yield of $588.7 \mathrm{mg} / \mathrm{L}$ in paddy straw filterate when $Z$. mobilistreatment was given as compared to Saccharomyces cerevisiae with $494.4 \mathrm{mg} / \mathrm{L}$ ethanol production. Goel and Wati (2016) studied ethanol production from paddy straw hydrolysate using 3 different yeast strains viz., $\quad S . \quad$ cerevisiae HAU-1, Pachysolentannophilus and Candida sp. and reported maximum $23.48 \mathrm{~g} / \mathrm{L}$ ethanol production after $96 \mathrm{~h}$ incubation at $35^{\circ} \mathrm{C}$ with $P$. tannophilus individually and $24.94 \mathrm{~g} / \mathrm{L}$ ethanol production when used as co-culture with $S$. cerevisiae HAU-1.

In conclusion, there is tremendous scope in nature for the isolation of cellulase producing microbial strains that can make lignocellulosic bio-ethanol production process 
economically viable. Further, hydrolytic efficiency of microbial strains can be improved by varying environmental and cultural conditions.

\section{Acknowledgement}

The authors thank Department of Microbiology, Chaudhary Charan Singh Haryana Agricultural University, Hisar for providing all the facilities for conducting this research.

\section{References}

AOAC. Official Methods of Analysis of AOAC international. (2000). Association of official analytical chemists. Gaithersburg, Maryland, USA, 17th edn, p. 14.

Ahmed, S., Bashir, A., Saleem, H., Saadia, M. and Jamil, A. (2009). Production and purification of cellulose degrading enzymes from a filamentous fungus Trichoderma harzianum. Pak. J. Bot.41(3): 141119.

Ali, U.F. and Saad El-Dein, H.S. (2008).Production and partial purification of cellulase complex by Aspergillus niger and A. nidulans grown on water hyacinth blend. $J$. Appl. Sci. Res., 4(7): 875-91.

Binod, P., Sindhu, R., Singhania, R.R., Vikram, S., Devi, L., Nagalakshmi, S., Kurien, N., Sukumaran, R.K. and Pandey, A. (2010). Bioethanol production from rice straw: An overview. Biores. Technol. 101: 476774.

Caputi P, Vede JM and Brown T. (1968). Spectrophotometric determination of chromic complex formed during oxidation of ethanol. Am J Enol Vitic, 19: 1601.
Classen, P.A.M., VanLier, J.B., LopezContreras, A.M., VanNiel, E.W.J., Sijtsma, L., deVries, S.S., Weusthuis, R.A. and VanNiel, E.W.J. (1999).Utilization of biomass for the supply of energy carriers. Appl. Microbiol. Biotechnol.52: 741-55.

Coughlan, M.P. and Ljungdahl, L.G. (1988). Comparative biochemistry of fungal and bacterial cellulolytic enzyme system. In: Aubert, J.P., Beguin, P., Millet, J. (Eds.), Biochemistry and Genetics of Cellulose Degradation. pp. 11-30.

Galbe, M. and Zacchi, G. (2002). A review of the production of ethanol from softwood. Appl. Microbiol. Biotechnol. 59: 618-28.

Gaur, R. and Tiwari, S. (2015). Isolation, production, purification and characterization of an organic solvent thermostable Alkaliphilic cellulase from Bacillus vallismortis RG-07. BMC Biotechnology. 15:19 DOI 10.1186/s12896-015-0129-9.

Gaurav, M.S. and Geeta, G.S. (2007). Effectiveness of fungal pretreatment of agro residues on ethanol production by yeasts and Zymomonas mobilis. Karnataka J. Agric. Sci., 20(2): 30104.

Ghosh TK, (1987). Measurement of cellulase activities. Pure Appl. Chem, 59: 257.

Goel, A. and Wati, L. (2013). Ethanol production from lignocellulosic materials. Int. J. Innov. Bio-sciences. 3(3): 111-14.

Goel, A. and Wati, L. (2016). Ethanol production from rice (Oryza sativa) straw by simultaneous saccharification and co-fermentation. Ind. J. Experiment. Biol., 54: 525-29.

Green, A.L., and Hughes, W.L. (1955). Protein fractionation on the basis of solubility solutions of salts and organic solvent. In: Methods in 
Enzymology (P. Colowick and $\mathrm{O}$. Kaplan Eds.) Acad. Press, New York.1: pp. 67.

Gupta P, Samant K and Sahu A. (2012). Isolation of cellulose degrading bacteria and determination of their cellulolytic potential. Int. J. Microbiol. Vol. 2012 Article ID 578925, 5 Pp. doi:10.1155/2012/578925.

Juhasz T, Szengyel Z, Reczey k, sika-Aho M and Viikari L (2005). Characterization of cellulases and hemicellulases produced by Trichoderma reesei on various carbon sources. Process Biochemistry.40(11): 3519-3525.

Kovacs, K., Szakacs, G. and Zacchi, G. (2009).Comparative enzymatic hydrolysis of pretreated spruce by supernatants, whole fermentation broths and washed mycelia of Trichoderma reesei and Trichoderma viride. Biores. Technol. 100: 1350-1357.

Mandels, M. and Sternberg, D. (1976). Recent advances in cellulase technology. J. Ferment. Technol.54: 267.

Miller GL, (1959). Use of dinitrosalicylic acid reagent for estimation of reducing sugars. Anal Chem, 31: 426.

Nakamura, Y., Sawada, T. and Inoue. E. (2001). Enhanced ethanol production from enzymatically treated steamexploded rice straw using extractive fermentation. J. Cem. Tech. Biotechnol.76: 879-884.

Oberoi, H.S., Vadlani, P.V., Brijwani, K., Bhagav, V.K. and Patil, R.T. (2010). Enhanced ethanol production via fermentation of the rice straw with hydrolysate-adapted Candida tropicalis ATCC 13803. Prog. Biochem. 45: 1299-1306.

Ohmiya, K., Sakka, K., Karita, S. and Kimura, T. (1997). Structure of cellulases and their applications. Biotechnol. Genet. Eng. Rev.14: 365413.

Patagundi B I, shivasharan C T and Kaliwal B B (2014). Isolation and characterization of cellulase producing bacteria from soil Int.J.Curr. Microbiol. App.Sci. 3(5): 59-69.

Shanmugapriya K, Saravana P.S. Krishanpriya, Manoharan M, Mythilli A and Joseph S. (2012). Isolation, screening and partial purification of cellulase from cellulase producing bacteria. Int. J. Adv. Biotechnol.Res. 3(1): 509-14.

Wati, L., Kumari, S. and Kundu, B.S. (2007). Paddy straw as substrate for ethanol production. Indian J. Microbiol. 47: 26-29.

\section{How to cite this article:}

Monika Agarwal, Annu Goel and Leela Wati. 2018. Ethanol Production from Paddy Straw using Partially Purified Fungal Cellulase. Int.J.Curr.Microbiol.App.Sci. 7(08): 3709-3719. doi: https://doi.org/10.20546/ijcmas.2018.708.376 